There is a doubt raised in the reports of the Board of Trade, whether the atmospheric system has been sufficiently tested to justify the preference of a line which can only be worked on the atmospheric system, or which presents gradients less favorable than a competing line for the use of the locomotive engine.

If it were practicable to suspend all railway legislation until the result of the Devon and Cornwall, and of the Epsom and Croydon Atmospheric lines were known, it would be perhaps the most cautious and prudent course to wait that result; but such a course, independent of all considerations of expediency, is evidently impracticable. Your Committee venture, therefore, to express their opinion to the House, that in deciding between competing lines of railway, those which have been set out to suit the atmospheric principle ought not to be considered as open to valid objection merely on account of their having gradients too severe for the locomotive, nor should they be tested in comparison with other lines solely by the degree of their suitableness to the use of the locomotive.

No doubt in matters like these experience alone can decide the ultimate result, but your Committee think that there is ample evidence which would justify the adoption of an atmospheric line at the present time. All the witnesses they have examined concur in its mechanical success. Mr. Bidder says, "I consider the mechanical problem as solved, whether the atmosphere could be made an efficient tractive agent. There can be no question about that; and the apparatus worked, as far as I observed, very well. The only question in my mind was as to the commercial application of it." Mr. Stephenson admits that under certain circumstances of gradients, $(1315$,$) and$ under certain circumstances of traffic without reference to gradients, (1204,) the atmospheric system would be preferable.

While your Committee have thus expressed a strong opinion in favor of the general merits of the atmospheric principle, they feel that experience can alone determine under what circumstances of traffic or of country the preference to either system should be given.

Railway Mag.

First Annual Report of the Directors of the South Carolina Railroad Company, for the year ending December 31st, 1844.

Charleston, S. C., Feb. 11 th, 1845.

The Directors of the South Carolina Railroad Company have the honor to submit herewith their First Annual Report, for the year ending on the 31st of December, 1844 . Since the last annual meeting at Columbia of the Stockholders of the Lonisville, Cincinnati and Charleston Railroad Company, and of the South Carolina Canal and Railroad Company, the consolidation of these two Companies, under an act of the Legislature of South Carolina, bearing date the 19th December, 1843, has been perfected; and all the chartered "Rights, Privileges and Property" of both are now centered in and enjoyed by one corporation, under the name of the South Carolina Railroad Company. 
The gross receipts, current expenses, and nett income, on the two Roads, previous to consolidation, for the year 1843, were:

From 1st Jan. to 1st July, on Hamburg Road, " " " on Columbia Branch,

$\$ 171,241.48$

$44,740.73$

Total,

Current Expenses on Hamburg Road, $\$ 103,147.76$

Current Expenses on Columbia Branch, 20,108.86

Interest on sterling Bonds and floating . note debt,

$\approx 15,982.21$

$59,000.00$

Nett Income,

$182,256.62$

$33,725.59$

From 1st July to 31st Dec., 1843, on Hamburg Road,

$177,074.03$

" " " " on Columbia Branch,

$49,835.01$

$226,904.04$

Current Expenses on Fiamivury Ruau, iucluding three Locomotives,

Current Expenses on Columbia Branch,

Interest on sterling Bonds and foating note debt,

$$
\begin{array}{r}
\$ 111,673.16 \\
18,437.52 \\
\\
59,000.00
\end{array}
$$

Neít incomé,

$139,110.68$

$\$ 37,798.36$

From which nett incomes the Board of Directors declared, for the first halt-year, a dividend of $\$ 1$ per silare; and from the last half-year $\$ 1.25$ per share, making for the year $\$ 2.25$ on each share, and equivalent to 3 per cent. on the par value of $\$ 75$ on the Road stock.

The above statement of expenditures and nett revenue would not seem to accord, on comparison, with the statements made in the report of 1843. In that exhibit, as the Companies had not been consolidated, and the interest on the sterling bonds and floating debt of the Louisville, Cincinnati, and Charleston Railroad Company had been previously provided for out of the funds of that Company, and charged in their books-it was not, and very properly, by the Auditor of the South Carolina Canal and Railroad Company, brought into the account of current expenses paid by him against the Railroad income. As under the head of current expenses, is now correctly embraced all these cliarges for interest, it was necessary, in a comparative exhibit of expenditures and of nett income for the two years, to embrace interest on bonds and note debt in those for 1843, as they had been embodied in the consolidated Company account for 1844 .

The gross receipts, current expenses, and nett income, for the year 1844, on the Roads, as consolidated, were:

From 1st January to 1st July, receipts,

Expenses, including one locomotive and extra burden cars,

$244,035.14$

$185,438.07$

Nett income,

Vol. $\mathrm{X}, 3$ ri Skrifs.-No. 3. - Septembia, 1845.

$58,597.07$ 
From 1st July to 1st January, 1845, receipts,

Expenses, including two locomotives, patents, extra

passenger and burden cars, and machinery,

Nett income,

$\$ 81,598.57$

From the above a dividend of $\$ 1.50$ was declared on each share for the first half year, and $\$ 2.25$ for the last half year, making $\$ 3.75$ on each share, and equivalent to 5 per cent. interest on the par cost on each share now represented in the Company. From the exhibit now made, it appears that the gross receipts for the year 1844 exceeded those of 1843 by $\$ \$ 9,967.70$, and the nett profits by $\$ 68,671.69$, while the current expenses, for the same period, exceeded those of the previous year by $\$ 21,305$. This statement goes to confirm, in part, a fact previously brought to the notice of the stockholders, that an increase of business on a railroad does not necessarily involve a corresponding increase of current expenses, where the Company is properly prepared with locomotives, and the requisite number of cars, to meet the business offered. The fixed capital is in the roadbed, and an appropriation or but one-tenth of that amount for an increase of motive power, may more than double or quadruple the capacity of the Company to do the business offered, and at a very inconsiderable augmentation of what may legitimately be charged to current expenses. In the expenditures, however, brought under this head, on the South Carolina Railroad, are included \$21,025 for three new locomotives and extra wheels; $\$ 17,498$ for new passenger and burden cars; $\$ 2400$ for patents for spark arresters and chilled boxes, and $\$ 775$ for extra permanent machinery in the work-shops. If from these various appropriations to permanent objects, and amounting in the aggregate to $\$ 41,698$, be deducted $\$ 23,561.50$, the amounts expended on similar objects, as shown in the report for 1843 , we would have $\$ 18,027$ to be deducted from $\$ 21,305$, the excess of current expenditures for 1844 , which would reduce that sum to $\$ 3278$, and show that an increase of 20 per cent, on the gross income of the Road from freight and passengers, involved an increase of but one per cent. on the legitimate current expenditures, and exhibit the encouraging result of 90 per cent. on the nett revenue.

The statements from the Auditor which accompany this report, will exhibit a satisfactory account of the property, the liabilities, and the available assets of the South Carolina Railroad Company, as now consolidated. To the tabular statement, No. 6, the attention of the Stockholders is particularly invited, as exhibiting, on one sheet, a perfect synopsis of the business transactions of the South Carolina Canal and Railroad Company, for each half year from the commencement of operations in the year 1830 , to the 1st of January, 1845, including the year 1844, of consolidation with the Louisville, Cincinnati, and Charleston Railroad Company.

This is an interesting paper, exhibiting the number of locomotives in service; the trips and number of miles performed; the income received, and the fluctuations in the trade and travel on the Road, and developing results instructive to those charged with the direction and 
management of railways; where economy of expenditure and cheapness of transportation are so dependent on the proper construction and judicious application of the powers of the locomotive. This is the great desideratum to be attained in all operations where machinery is used, and of vast importance to railroads, as the element on which their triumph over all other conveyances and success must finally rest. These views cannot be stronger illustrated than by comparing from the table, the operations of the first with the last half years of 1843 and 1844. In the first half years, 15 locomotives in service, made 2,036 arrivals and departures ; ran over 319,968 miles; transported 130,366 bales of cotton and 48,722 passengers, and realized in money, including the freight on merchandize and the mails, $\$ 460$,057.35. In the last halves of the same years 16 locomotives in service, making 1,904 arrivals and departures, and running 304,752 miles; 132 arrivals and departures, and 14,216 miles less than in the first halves of the same years; transported 184,319 bales of cotton, 43,164 passengers, and realized for the Road $\$ 515,743.85$ in money; shewing that with but one additional engine, and less miles and trips performed, an increase of 53,953 bales of cotton-a decrease of 5558 in the number of passengers, and an augmentation in the moneyed receipts of $\$ 55,686.50$. The decrease in the passengers is explained by the facts of two Methodist Camp Meetings in the spring of 1844, at Ladson's Station and the Cypress, and at which it was estimated there were between 5 and 6000 attendants. Another comparison between the years 1842 and 1844, will serve to illugtrate the powers and advantages of the larger class of locomotives, six (6) of which have been added the last two years, to the $2 \mathrm{~d}$ and $3 \mathrm{~d}$ class engines previously used on the Road. In the year 1842, the year previons to the consolidation of the two Roads, 14 engines in service made 1809 arrivals and departures; performed 286,995 miles; transported 92,336 bales of cotton and 33,925 passengers, and realized in money for the Road $\$ 408,704.87$.

In 1844, 17 locomotives are returned as having made 1964 arrivals and departures, run over 310,812 miles, and transported 186,638 bales of cotton and 54,146 passengers-and realized on the whole, including freight on merchandise and the mail, $\$ 532,869.85$, shewing with but three additional engines, an increase of 94,302 bales of cotton, 20,221 of passengers, and $\$ 124,164.93$ on the gross income, being at the rate of 100 per cent. on praduce, 60 per cent. on the number of passengers, and 31 per cent. on the moneyed receipts. The increase on the moneyed reciipts does not bear the same proportion to the increase on the quantity of the freight and number of passengers, and which is to be explained by the modification and reduction made on the rates of freight and passage in 1844. In 1842, the fare for passengers was 18 per cent; ; on merchandise, from $12 \frac{1}{2}$ to 15 per cent.; and on cotton and weight freight, from 30 to 40 per cent. higher than it was in 1844. At the same rate of freights, provided the same amount of business could have been commanded, the increase on the moneyed receipts, on the transportation performed, would have been full 25 per cent. greater. 
The subject of the rates for freight and passage on railroads, must be relative, and be governed by the quantity of business and number of passengers offering, and the competition with other common carriers. To meet a competition which is daily increasing from the number of new Roads in the United States, which have been constructed; and from the improvements in, and new application of, machinery, to steam navigation, it will be necessary to be governed in some degree by the fares established by other common carriers, contending for the same business; or forfeit the claim of the South Carolina hoad to a fair participation in it. By this policy, in regnlating a Tariff for Freight and Passengers, your Directors have been governed; and they will continue, in the future, as they have in the past, to bestow on this, as on all other subjects, affecting the interests of this Company, the consideration of their most matured judgments.

With these Tables, is one shewing the number of Grades and their lengths; with the lengths of the different curves and straight lines; the distance between the different stations and depots, and their relative elevations; with the elevations of each point above tide water ; on the road between Branchville and Columbia. A similar table we have in preparation for the Charleston and Hamburg Road, which has not yet been perfected, for the want of the necessary documents.

The Report of Mr. G. I3. Lythgoe, the Superintendent of the Road, shews that under his vigilant supervision, the track and embankments have been preserved in the same good condition represented to be in the previous year. He states, however, what has been long since apprehended, that the heads of the piles, sustaining the cross-ties and superstructure, on the Hamburg Road, are beginning to exhibit decay, and to obviate this defect, it will become necessary to lay mud sills on the top of the piles. That, if this work is commenced immediately, its expense may be distributed through consecutive years; and therefore recommends that twenty miles of the road, for the next four years, be so improved, which will probably involve an increased expense for timber and labor, of $\$ 300$ per month.

On the Columbia road, which is generally in good order, it was found indispensable to renew some of the cross-ties, between Orangeburg and Branchville, the last spring and summer. As it is but four years and six months since that section of the road was finished, that fact goes to confirm the past convictions that the durability of pine timber at the South, exposed as the cross-ties are on the Columbia road, on the surface and but half covered with earth, cannot be depended on to exceed an average of five years; and that all timbered superstructures of roads, in Southern latitudes, will require renewal. within that period, or one-fifth each year for the whole extent. By way of experiment, six miles of the Columbia road was constructed of Cypress ties; but sufficient time has not yet elapsed to test their superior durability over pine, or their greater economy in the higher price. The durability of timber is a subject of deep interest to Railroad Companies : particularly as timber superstructures are beginning to claim a preference to those made of materials of a less yielding or elastic character; and has engaged the attention for many years of 
the suceessive Board of Directors of the South Carolina Canal and Railroad Company. The process of kyanizing, which was tested to a small extent, seemed to act favorably on the fibres of the wood to which it was applied; but the problem yet remains unsolved, whether the additional durability imparted is compensated by the extra expense incurred. The experiment with the mineral process, recothmended by Dr. Earle, and for which an appropriation was made by the South Carolina Canal and Railroad Company, Mr. Lythgoe thus remarks:- "I regret to say, the process of Earlizing sap timber will not answer the purpose intended: as we are now compelled to take all we have used out of the road as soon as we possibly can, in consequence of its having become so soft and decayed as to allow the iron to embed into it, thereby injuring the iron to a considerable extent." The report of Mr. Lythgoe represents that the expense of the maintenance of way on the Hamburg road the last year, has been $\$ 293$ per mile; which including the sum of $\$ 828$ expended in ditching and on embankment, equal to an average of $\$ 6$ per mile, makes the whole sum \$299 per mile. The expense of maintenance of way on the Columbia branch was but $\$ 135$ per mile, including $\$ 424$ incurred in ditching and embankments, makes 144.28 per mile. The difference in the expense per mile on the two roads, is explained by the different plan of construction, and the different ages of the roads; the timber, with the exception of one short section, on the Columbia road, not having had time yet to manifest decay or require renewal. The expense of maintenance of way on the Hamburg road, if preserved at the above standard, \$299 per mile, is as low, probably, as it can be reduced to; while some addition to the amount incurred for the same objects on the Columbia branch will become necessary, as the age of the road and the business on it increases.

The Report of Mr. Darrel, Master of the Workshops, presents the state and condition of the motive power owned by the Company: and a favorable statement of the quantity of work done in the Finishing and Smith-shops and Foundry, and on the Jocomotives rebuilding and repairing, the last year. From his report, it appears he received from his predecessor, as Master of the Shops, 23 locomotives of the $2 \mathrm{~d}$ and $3 \mathrm{~d}$ class; enumerating all which bore the name in the yard, and one new boiler finished. Of these locomotives, many of which had been in the service of the South Carolina Canal and Railroad Company from its commencement of business in the years ' 31 and ' 32,4 are stated to have been in good order; 7 defective, and somewhat disabled, but performing road service; 6 repairing and rebuilding, and 3 condemned; since which, 3 others of those disabled, have run their career, and been condemned, or laid up in ordinary for summer examination, and see to what profitable purposes they, or parts of them, can be applied. To the above locomotives have been added the last two years, 6 of Bald win and Whitney's six wheel connected locomotives of the $2 d$ class. Deducting the 6 which have been condemned, or laid up in ordinary, and one (1) that is rebuilding, 22 may be considered as in a condition to be made fit for road duty, under occasional repairs; from 16: to 17 of wich have been 
kept in active service during the year ending 31 st December, 1844, which is a very large proportion. It has been considered good policy, and particularly by those well acquainted with the delicate mechanism of the locomotive, so easily deranged, that Companies should own double the number that they can keep constantly and profitably employed : and the best regulated English and American roads preserve very nearly this proportion. Where the opposite policy is pursued, jocomotives often suffer, are soon destroyed, and rendered worthless, from the want of timely and effectual reparation. When the business of the road presses, and in no modes of transportation are the alternations from one extreme to the other so frequent as on railways, temporary expedients, where there is a deficiency for the time of power, must be resorted to; and engines, though slightly disabled and easily repaired, are too frequently forced, from necessity, on anther trip, to their more permanent injury, if not ruin; or taken in shop late at night, hastily overhauled, and rudely repaired by the light of the torch, so as to be replaced on the road, for service, in time next morning. It is difficult, under such arrangements, to preserve the locomotives in the best condition for profitable use; or to onduct the operations at the workshops, and regulate the transportarion on the road with economy and satisfaction.

The Joint Report of the General Agent, Mr. King, and the Agent of Transportation, Mr. Hacker, show that this Company now have in service, for the very large and increased business which has devolved on it, but 18 passenger and baggage cars, and 283 freight cars : 147 of which are of four wheels, with eanvass sides, and of inconsiderable burden: the whole of them not more than equal to acrommodate the loads for two engines. Of these, one 8 wheel passenyer, one 8 wheel baggage, thirty-two 8 wheel box, and fourteen $s$ wheel platform cars, have been added during the year 1844 , and at 1 cost to the company for wood work of $\$ 7020$, and for wheels and ixles, as reported by Master of Workshops, $\$ 10,478$-making for the whole, $\$ 17,498$. Both of these officers, and whose duties and remonsibilities afford them the best opportunity of forming correct opinious, concur in the necessity of an additional number of passenzer, baggage, and burden ears, to do the business of the road to the dest advantage, with punctnality, and to the satisfaction of travelers and shippers. The want of more suitable and more enlarged accommodations at the depots at Charleston, Hamburg and Columbia, is ine more strongly enforced by their testimony; and while these subfects have engaged the attention of the Board of Directors, whose term of service now expires, they cannot too strongly impress its im. portance on those who, by your selection, may be their successors in mifice for the present year. It may involve considerable expenditure in the first instance; but the interests of the Company and its security and protection from probable heavy loss, and its ability, through ac. tive agents, to discharge with exactness and despatch its varied responsibilities, as a common carrier, to all who travel and transport on the road, strongly recommend the necessity of more suitable, more sommodious, and more permanent buildings, at the workshops, and 
the three important depots at Charleston, Hamburg, and Columbia, than at present exist.

At the last Session of the Legislature, application was made by many of the citizens of Sumter and Kershaw, for aid in the form of a subscription, to assist in extending the South Carolina Railroad, under a provision in its charter, to Camden. That body declined perticipating in the enterprise as a Stockholder, but responded favorably to the application, so far as to authorize this Company to become Joint Stockholders with the citizens of that section of country through which the road to Camden was to pass, and as a motive for this Company so to co-operate in the work, an act was passect anthorizing the funding, at five per cent. interest, and on time, of a febt which accrued under the law reducing the stock in the Louisville, Cinciunati, and Charleston Railroad Company, and which now stands to the credit of the State in the books of said Company. A reference to the act will explain more satisfactorily its provisions. "To enable the Stockholders to act more advisedly on the subject, and at the particular solicitation of many of the citizens of Sumter and Kershaw, who had expressed an interest in the enterprise, a preliminary survey was ordered by the Board of Directors. Mr. Mac Rae, favorably known to the Stockholders, was charged with the service, and his report and approximate estimate of the probable cost of the work, is herewith respectfully submitted. His estimate is based on two plans of superstructure. In the one, where a wooden stringer and light iron rail is used, the cost is estimated at $\$ 450,000$. In the other, where a heavier 'T rail is used, and the plan is made to conform to that of the Columbia road, the cost is put down at $\$ 540,696$. In both estimates the present specific duty on rail iron at $\$ 25$ a ton is included-amounting to $\$ 60,000$ on the first, and $\$ 90,000$ on the last estimate. If the tax is remitted, or reduced to a revenue standard, there will be a corresponding decrease in the probable cost of the road.

The Board of Directors, with much satisfaction, now report to the Stockholders, the extension of the Georgia Railroad to Covington, twenty-five miles beyond its late terminus at Madison; and that the reporied progress in the section above, removes all doubts as to the road being completed to Whitehall, the point of junction with the Western and Atlantic Railroad, by September or October next, and in time for the opening of the fall business. At the same period, such is the progress now making with the work on the Western and Atlantic Railroad, that that road will be completed and in operation to the Oostanauly, eighty-four miles beyond Whitehall, and within fifty-six miles of the Tennes:ee river, at Chatanouga, and seventeen of the Coosa, at Rome.

Within the last twelve months the condition of the West Point and Montgomery Railroad has been greatly improved, and active measures taken to extend it some five or six miles east of Chehaw. At the late session of the Legislature of Alabama, the 2 per cent. land fund, amounting to about $\$ 240,000$, was appropriated in equal proportions, and on most favorable terms, to the completion of the West Point and Montgomery road to the Chattahoochee, and to that of a 
newly projected road connecting the Coosa, by Will's Creek Valley and the Sand Mountain, with Gunter's Landing on the 'Tennessee. All these events go to approve the late action and policy of a majority of your Board of birectors in co-operating to the extent of their ability wilh the Georgia Railroad and Banking Company, and the West Point and Montgomery Railroad Company, for the completion of their respective enterprises, estimating them as important links, in the great chain of railroad intercommunication connecting the extreme Eastern with the most South-western extremities of the Union $\rightarrow$ an enterprise in which not only this Company, but the City of Charleston and State of South Carolina, cannot but feel the deepest interest, and acknowledge the important influence its completion must have on the prosperity of each.

All of which is respectfully submitted by

$$
\text { James Gadsden, President. }
$$

To be Continued.

\section{Uniformity of Gage.}

No man can doubt the desirableness of one uniform gage, if at any reasonable cost it could be attained. Mr. Cobden has, therefore, done wisely in bringing it forward, even now late as it is.

Great difference of opinion existed at first among engineers as to what should be the proper gage. Most of them were of opinion that the present is too narrow, and perhaps if the whole was to be done over again, we should-have it something wider.

The reasons for a wider gage were thiefly two-one, that the present gage would be dangerous at high speeds, and the other, that it did not afford scope for that powerful machinery in locomotives necessary for attaining very high velocities. Greater research and experience have exploded the first, and along with it, one of the argumeuts of Mr. Brunel for his broad gáge. He asserted, that by increasing the gage he should be able to use higher wheels on the carriages and engines, and that these higher wheels on the carriages would work with less friction, and, therefore, more economy. The less friction with high wheels, we at first opposed, as being contrary to the results of experiment, which showed that slipping friction is independent of velocity, and the rolling friction on railways is insiguificant; and experience has taught Mr. Brunel that we were right, for he has abandoned his bigh wheels for carriages.

In respect of the engines, this fact is enough. 'There are, or were, about his Company's premises, engines with ten feet wheels, which cost some $£ 30,000$ or $£ 40,000$, and have never been used, for one very good and-to all other men's minds except Mr. Brunel's, until he tried them-very obvious reason, namely, that they did not possess the power to work. They are, of course, laid aside, and the Company have gradually come down to more reasonable dimensions, we believe from six or six and a half to seven feet wheels.

The second reason, that is, that the narrow gage does not afford room for machinery competent to compass high velocities, was no 